УДК 001.891:[378.018.8:373.5.011.3-051:80]:37.06

DOI:

Тетяна Григоренко, кандидат філологічних наук, дочент кафедри української мови та методики ї̈ навчання Уманського державного педагогічного університету імені Павла Тичини

\title{
ОРГАНІЗАЦІЯ ТА ПРОВЕДЕННЯ ДОСЛІДЖЕННЯ ЕФЕКТИВНОСТІ СИСТЕМИ ПІДГОТОВКИ МАЙБУТНІХ УЧИТЕЛІВ-ФІЛОЛОГІВ В УМОВАХ ОСВІТНЬО- КОМУНІКАТИВНОГО СЕРЕДОВИЩА ЗВО
}

У статті обтрунтовується система підготовки майбутніх учителів-філологів в умовах освітньокомунікативного середовища закладів вищої освіти, організація та проведення експериментальної перевірки. Подано методику й програму експериментального дослідження; описано організацію, хід і результати констатувального й формувального етапів експерименту; узагальнено результати експериментальноі роботи. Виявлено, що завдяки впливу активних факторів, а саме, запропонованим нами педагогічним умовам, можна досягти потрібних результатів.

Ключові слова: учителі-філологи; освітньо-комунікативне середовщще; педагогічне дослідження; професійно-комунікативна діяльність; система підготовки майбутніх учителів-філологів; педагогічні умови підготовки майбутніх учителів-філологів; природний експеримент; методи дослідження.

Табл. 1. Літ. 7.

Tetyana Hryhorenko, Ph.D.(Philology), Associate Professor of the Ukrainian Language and Methods of Teaching Department, Uman Pavlo Tychyna State Pedagogical University

\section{ORGANIZATION AND CARRYING OUT THE RESEARCH OF EFFICIENCY OF FUTURE TEACHERS-PHILOLOGISTS' TRAINING SYSTEM IN THE CONDITIONS OF THE EDUCATIONAL AND COMMUNICATIVE ENVIRONMENT OF HEI}

The article substantiates the future teachers-philologists' training system in the educational and communicative environment of higher education institutions, the organization and conduct of experimental testing. The scientists views on the stages and methodology of pedagogical research have been analyzed. As well as the features of the pedagogical experiment conducted by the author to confirm the effectiveness of the future teachers-philologists training system in the educational and communicative environment of higher education institutions have been described.

It is determined that pedagogical research should be based on precisely established facts that allow its empirical verification; it should be based on already known philosophical, sociological, psychological or pedagogical theories, be purposeful, systematic, have the relationship of all elements, procedures, methods. It must reflect the subject of research in its own internal logic. It requires the use of methods or system of methods that would fully comply with the internal logic of the phenomenon or process being studied.

The study uses a natural experiment that allows interaction with teachers of philology in normal learning conditions, and the influences themselves are invisible to the minds of students. The research and experimental work has been carried out in stages in the natural conditions of the educational process from 2014 to 2020. For the representativeness of the sample, 536 respondents from seven educational institutions of Ukraine were involved in the pedagogical experiment.

Changes in the level characteristics of the formation of indicators of readiness of future teachers of philology for professional and communicative activities of EG and CG between the ascertaining and final stages of the pedagogical experiment are recorded. In the experimental group, the number of students with a low (reproductive) level decreased by $32.34 \%$ and increased by $21.19 \%$ with a medium (productive) level and by $11.15 \%$ with a high (professional) level. In the control group, the number of students with a low (reproductive) level decreased by $9.74 \%$ and increased by $6.37 \%$ with a medium (productive) level and by $3.37 \%$ with a high (professional) level.

The results of the research and experimental work confirmed the effectiveness of the future teachers-philologists ' training system in the educational and communicative environment of higher education institutions. It defined and tested pedagogical conditions that in unity and interrelation contribute to the effectiveness of future teachersphilologists to professional communication in the conditions of ACS of institutions of higher education.

Keywords: teachers-philologists; an educational and communicative environment; pedagogical research; professional and communicative activity; the teachers-philologists' training system; pedagogical conditions for training teachers of philology; natural experiment; research methods.

П остановка проблеми. Для забезпечення ефективності системи підготовки майбутніх учителів-філологів в умовах освітньо-комунікативного середовища (далі -

ОКС) закладів вищої освіти необхідна експериментальна перевірка запропонованих педагогічних умов. У ході їхнього застосування планується отримати результати, що 


\section{ОРГАНІЗАЦІЯТАПРОВЕДЕННЯ ДОСЛДЖЕННЯЕФЕКТИВНОСТІСИСТЕМИПДГОТОВКИМАЙБУТНІХ УЧИТЕЛІВ-ФІЛОЛОГІВ В УМОВАХОСВІТНЬО-КОМУНІКАТИВНОГОСЕРЕДОВИЩАЗВО}

характеризуватимуть передбачувані можливості та переваги авторської методики. Якісні та кількісні характеристики рівнів сформованості компонентів готовності майбутніх учителівфілологів до професійно-комунікативної діяльності - це основний показник ефективності підготовки майбутніх учителів-філологів. Вибір методів педагогічного дослідження та їхнє застосування під час проведення педагогічного експерименту $\epsilon$ актуальним.

Питання методології та методики педагогічних досліджень розглядались уроботах С. Архангельського, Ю. Бабанського, В. Безпалько, Н. Кузьміної, Р. Нємова та ін. У вітчизняній педагогіці підходи до організації досліджень й обробки їх результатів запропоновані П. Воловиком. Б. Гершунським, С. Гончаренко, I. Підласим та ін. На нашу думку, найефективніше обгрунтування теоретичних 1 методичних засад підготовки майбутніх учителівфілологів в умовах ОКС закладів вищої освіти буде підтверджено за допомогою педагогічного експерименту.

Метою статті є теоретичний аналіз поглядів науковців на етапи та методологію проведення педагогічного дослідження, а також опис особливостей педагогічного експерименту, що проводився автором 3 метою підтвердження ефективності системи підготовки майбутніх учителів-філологів в умовах ОКС закладів вищої освіти.

Виклад основного матеріалу. Педагогічне дослідження - це “процес і результат наукової діяльності, спрямовані на одержання нових знань про закономірності процесу навчання, виховання і розвитку особистості, про структуру, теорію, методику і технологію організації навчальновиховного процесу, його зміст, принципи, організаційні методи і прийоми”, на думку C. Гончаренко [3, 23]. Автор висунув деякі вимоги щодо проведення науково-педагогічного дослідження. Тобто, воно має грунтуватися на точно встановлених фактах, які допускають його емпіричну перевірку; воно має опиратися на вже відомі філософські, соціологічні, психологічні чи педагогічні теорії, бути цілеспрямованим, систематичним, мати взаємозв'язок всіх елементів, процедур, методик; воно повинно відображати предмет дослідження в його власній внутрішній логіці; у ньому обов'язковим $\epsilon$ застосування методів або системи методів, які б повністю відповідали внутрішній логіці явища чи процесу, що вивчається [3]. Спосіб вивчення педагогічних явищ - це методи педагогічного дослідження [6, 17]. Колектив авторів [6] пропонує розділити методи на три групи: вивчення педагогічного досвіду, методи теоретичного дослідження й математичні методи. В. Краєвський групує їх на емпіричні й теоретичні $[7,105]$. У своїх роботах Н. Пєйсахов поділяє методи на емпіричні, експериментальні та теоретичні $[5,11]$. У нашому дослідженні ми використовували методи теоретичні, емпіричні та математичної статистики.

Для перевірки результативності рівнів сформованості компонентів готовності майбутніх учителів-філологів до професійно-комунікативної діяльності нами проведено педагогічний експеримент, який здійснювався за трьома етапами: констатувальним, формувальним, контрольним. "Експеримент дає можливість, зазначає Г. Ващенко, - робити спостереження в такій кількості й протягом такого часу, як це потрібно для досконалого вивчення явища. ... В експерименті $є$ змога розкласти явище на його складові елементи і вивчати кожен з них зокрема" $[1,123]$. Вибір педагогічного експерименту зумовлено тим, що в ньому реалізують кілька (або всі) його функцій: перевірка істинності теоретичних тверджень дослідника, оновлення змісту педагогічної науки, пізнання сутності взаємозв'язків педагогічних явищ, висловлення нових припущень, витлумачення фактів із погляду сьогодення. Дослідник має забезпечити єдність організації педагогічного експерименту та реального освітнього процесу, провести експеримент в умовах, які дадуть змогу використовувати його результати в освітній практиці [4, 28-29].

Експеримент - метод збирання педагогічних фактів у спеціально створених умовах, що дають змогу вивчати й перевіряти педагогічні впливи згідно з проблемами дослідження [2]. Розрізняють два види експерименту: лабораторний i природний. У дослідженні застосовано природний експеримент, що допускає взаємодію з викладачами-філологами у звичайних умовах навчання, а самі впливи є непомітними для свідомості студентів. Дослідницько-експериментальна робота проведена поетапно в природних умовах освітнього процесу з 2014 р. до 2020 р. Для репрезентативності вибірки до педагогічного експерименту було залучено 536 респондентів Уманського державного педагогічного університету імені Павла Тичини, Хмельницького національного університету, Криворізького державного педагогічного університету, Мукачівського державного університету, Комунального закладу “Харківська гуманітарнопедагогічна академія” Харківської обласної ради, Волинського інституту післядипломної освіти, 


\section{ОРГАНІЗАЦІЯТАПРОВЕДЕННЯ ДОСЛДЖЕННЯЕФЕКТИВНОСТІСИСТЕМИПДГОТОВКИМАЙБУТНІХ УЧИТЕЛІВ-ФІЛОЛОГІВ В УМОВАХ ОСВІТНЬО-КОМУНІКАТИВНОГОСЕРЕДОВИЩАЗВО}

Закарпатського угорського інституту імені Ференца Ракоці II, та сформовані експериментальна (ЕГ) і контрольна (КГ) групи, однакові в якісному вимірі.

На констатувальному етапі дослідження сформовано цілісну методику “Діагностика готовності майбутніх учителів-філологів до професійно-комунікативної діяльності”, до якої ввійшли анкети й методи інших науковців. Велика частина анкет і методів творчо опрацьована й адаптована відповідно до дослідження.

Для початкової діагностики поєднано такі методики:

- методики, спрямовані на визначення рівня сформованості мотиваційно-иіннісного компонента готовності до професійнокомунікативної діяльності (методика Т. Ільїної, тест та методика Т. Елерса, методика Р. Бабушкіна, тест С. Бубнової, тест М. Рокича, тест Ю. Тодорцевої);

- методики, зорієнтовані на визначення рівня когнітивно-комунікативного компонента готовності до професійно-комунікативной діяльності (опитувальник на діагностику задоволеності студентів професійною підготовкою; діагностична анкета для визначення рівня методичної підготовки);

- методики, сфокусовані на визначення рівня діяльнісно-практичного компонента готовності до професійно-комунікативної діяльності (методика О. Джерелюк, тест Н. Вишнякової);

- методики, спрямовані на визначення рівня професійно-особистісного компонента готовності до професійно-комунікативної діяльності (методика Г. Айзенк, адаптована О. Шмєльовим; діагностика за методикою Дж. Брунера; тест на визначення творчого потенціалу особистості; діагностика стратегій розв'язання конфліктних ситуацій Д. Джонсона і Ф. Джонсона; методика Б. Пашнєва);

- методики, зорієнтовані на визначення рівня очінно-рефлексивного компонента готовності до професійно-комунікативної діяльності (методика діагностики рівня розвитку рефлективності (адаптована за А. Карповим); тест "Рівень самооцінювання й саморозвитку"; опитувальник “Самооцінювання професійних якостей майбутнього вчителя-філолога”; тест “Самооцінювання творчого потенціалу особистості”).

У системі методичної роботи на аналізованому етапі (перед апробацією системи) педагогічні колективи були ознайомлені 3 концептуальними засадами підготовки майбутніх учителів-філологів до професійно-комунікативної діяльності в умовах ОКС закладів вищої освіти.

На формувальному етапі упроваджено систему підготовки майбутніх учителів-філологів в умовах ОКС закладів вищої освіти, який завершився підсумковою діагностикою, спрямованою на з'ясування рівня готовності майбутніх учителів до професійно-комунікативної діяльності.

На узагальнювальному етапі систематизовано та статистично оброблено експериментальні дані; сформульовано основні висновки й рекомендації щодо впровадження результатів педагогічного експерименту в процес підготовки майбутніх учителів-філологів, окреслено перспективи подальшого вивчення проблеми.

ЕГ і КГ сформовані так: за результатами вхідного тестування середній бал в ЕГ становив 73,54 ; у КГ - 74,59; якість знань в ЕГ - 71,38 \%, у КГ - 72,66 \%. Респонденти дослідних груп на початку констатувального етапу педагогічного експерименту мали практично однакові показники параметрів вимірювань, що забезпечувало чистоту й об'єктивність початкових показників для проведення педагогічного експерименту.

Згідно з гіпотезою, після завершення експерименту рівень наявних знань 3 фахових дисциплін в експериментальній групі буде вищим, ніж в учасників контрольної групи.

У дослідженні зафіксовано зміни рівневих характеристик сформованості показників готовності майбутніх учителів-філологів до професійно-комунікативної діяльності ЕГ та КГ між констатувальним і формувальним етапами педагогічного експерименту. В експериментальній групі зменшилася кількість студентів із низьким (репродуктивним) рівнем на 10,78 \% і збільшилася на $3,72 \%$ із середнім (продуктивним) рівнем та на 7,07\% із високим (професійним) рівнем. У контрольній групі зменшилася чисельність студентів із низьким (репродуктивним) рівнем на $3,00 \%$ та на $1,49 \%$ із високим (професійним) рівнем і збільшилася на 4,49 \% із середнім (продуктивним) рівнем.

Це аргументоване тим, що в експериментальному освітньомупроцесі використано систему підготовки майбутніх учителів-філологів до професійнокомунікативної й апробовано педагогічні умови підготовки майбутніх учителів-філологів в умовах ОКС закладів вищої освіти, що дало змогу створити в навчальному процесі підготовки майбутніх учителів-філологів в ЕГ якісно нові умови освітньої діяльності. 

УЧИТЕЛІВ-ФІЛОЛОГІВ В УМОВАХОСВІТНЬО-КОМУНІКАТИВНОГОСЕРЕДОВИЩАЗВО

У таблиці 1 зафіксовано зміни рівневих характеристик сформованості показників готовності майбутніх учителів-філологів до професійно-комунікативної діяльності ЕГ та КГ між констатувальним і завершальним етапами педагогічного експерименту. В експериментальній групі зменшилася кількість студентів із низьким (репродуктивним) рівнем на 32,34 \% і збільшилася на $21,19 \%$ із середнім (продуктивним) рівнем та на $11,15 \%$ із високим (професійним) рівнем. У контрольній групі зменшилася чисельність студентів із низьким (репродуктивним) рівнем на $9,74 \%$ і збільшилася на $6,37 \%$ із середнім (продуктивним) рівнем та на $3,37 \%$ із високим (професійним) рівнем.

Висновок. Отже, результати дослідницькоекспериментальної роботи підтвердили ефективність реалізації системи підготовки майбутніх учителів-філологів в умовах ОКС закладів вищої освіти, визначених й апробованих педагогічних умов, що в єдності та взаємозв'язку сприяють результативності формування готовності майбутніх учителів-філологів до професійно-комунікативної діяльності в умовах ОКС закладів вищої освіти. Зроблені висновки дають підстави стверджувати, що мети досягнуто, завдання - виконані, гіпотезу дослідження доведено.

Перспективи подальших розвідок у цьому напрямі. Враховуючи те, що до сьогодні чинним є лише проєкт Стандарту вищої освіти (2017) зі спеціальності 035. “Філологія”, зокрема, 035.01 - українська мова та література, другого (магістерського) рівня, доцільно посилювати увагу до формування готовності майбутніх учителів-філологів до професійно-комунікативної діяльності в умовах ОКС закладів вищої освіти, що $є$ важливою педагогічною проблемою і стимулювальним чинником стійкого розвитку вищої освіти України загалом.

\section{ЛІТЕРАТУРА}

1. Ващенко Г. Г. Загальні методи навчання : підруч. для педагогів. Київ : Всеукраїнське педагогічне товариство ім. Г. Ващенка, 1997. 410 с.

2. Волков Б. С., Волкова Н. В. Детская психология : логические схемы. Москва : Владос, $2002.256 \mathrm{c}$.

3. Гончаренко С. У. Педагогічні дослідження : методологічні поради молодим науковцям. Київ ; Вінниця : Планер, 2010.308 с.

4. Панасенко Е. Зміст і структура експерименту як методу наукового дослідження у теорії та практиці вітчизняної педагогіки (1945-1991). Рідна школа. 2011. № 11. С. 28-35.

5. Педагогика высшей школы : учеб-метод. пособ. / науч. ред. Н. М. Пейсахов. Казань : Издво Казанского ун-та, 1985. 190 с.

6. Педагогика: педагогические теории, системы, технологии : учеб. для студ. высш. и сред. пед. учеб. завед / С. А. Смирнов, И. Б. Котова, Е. Н. Шиянов и др. ; под ред. С. А. Смирнова. 4-е изд., испр. Москва : Академия, 2003. 512 с.

7. Педагогика : учеб. пособ. для студ. пед. вузов ипед. колледжей / под. ред. П. И. Пидкасистого. Москва : Педагогическое общество России, 2004. $608 \mathrm{c}$.

\section{REFERENCES}

1. Vashchenko, H. H. (1997). Zahalni metody navchannia [General Teaching Methods]. Kyiv, 410 p. [in Ukrainian].

2. Volkov, B. S. \& Volkova, N. V. (2002). Detskaya psihologiya : logicheskie skhemy [Children's Psychology : Logical Schemes]. Moscov, 256 p. [in Russian].

3. Honcharenko, S. U. (2010). Pedahohichni doslidzhennia : metodolohichni porady molodym naukovtsiam [Educational Studies : Methodological Advice to The Young Researchers]. Kyiv; Vinnytsia, 308 p. [in Ukrainian].

4. Panasenko, E. (2011). Zmist i struktura eksperymentu yak metodu naukovoho doslidzhennia u teorii ta praktytsi vitchyznianoi pedahohiky (19451991 rr.) [Content and structure of the experiment as a method of scientific research in the theory and practice of domestic pedagogy (1945-1991)]. Native school, no. 11, pp. 28-35. [in Ukrainian].

5. Pejsahov, N. M. (Ed.). (1985). Pedagogika vysshej shkoly [University Pedagogics]. Kazan, 190 p. [in Russian].

6. Smirnov, S. A., Kotova, I. B. \& Shiyanov, Ye. N. et al. (2003). Pedagogika: pedagogicheskie teorii, sistemy, tekhnologii [Pedagogics: pedagogical theories, systems and technologies].(Ed.). Smirnov, S. A., 4 ed., Moscov, 512 p. [in Russian].

7. Pidkasistyi, P. I. (Ed.). (2004). Pedagogika [Pedagogics]. Moscov, 608 p. [in Russian].

Стаття надійшла до друку 23.10.2020

\section{G58080

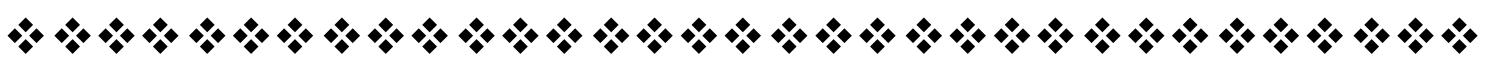

